\title{
SIMPLIFIED DESIGN MODEL FOR UNI-AXIALLY LOADED DOUBLE-SKINNED CONCRETE-FILLED-STEEL-TUBULAR COLUMNS WITH EXTERNAL CONFINEMENT
}

\author{
J.C.M. $\mathrm{Ho}^{1}$ and C.X. Dong ${ }^{2}$ \\ 1 *Senior Lecturer, School of Civil Engineering, The University of Queensland, Brisbane, QLD 4072, Australia \\ ${ }^{2} P h D$ Student, Department of Civil Engineering, The University of Hong Kong, Hong Kong \\ *(Corresponding author: E-mail: johnny.ho@uq.edu.au)
}

Received: 5 December 2012; Revised: 4 January 2013; Accepted: 16 December 2013

\begin{abstract}
One of the significant contributions of using double-skinned concrete-filled-steel-tubular (CFST) columns is that it can extend the maximum limit of concrete strength that can be practically used in the construction industry, by improving the ductility of columns through providing more uniform and continuous confining pressure to the in-filled concrete. However, because of the imperfect interface bonding occurs at early stage, the elastic strength and stiffness will decrease so that the confinement effect provided by the steel tube is not fully utilized. To improve the situation, the authors have proposed to use external confinement in the form of steel rings on the outer steel tube to restrict the dilation of CFST columns and thus restore an intact interface bonding condition. It has been verified by uni-axial compression test that the elastic strength, stiffness and interface bonding were improved. Based on the test results, the authors have developed a theoretical model for predicting the uni-axial load-carrying capacity of doubled-skinned CFST columns. As a continued study, the authors will investigate the most critical parameters affecting the uni-axial strength, and to develop a simplified formula for practical design of doubled-skinned CFST columns through an extensive parametric study.
\end{abstract}

Keywords: Columns, Concrete-filled, Double-skin tubular, External confinement, Rings

\section{INTRODUCTION}

High-strength concrete (HSC) of concrete strength about 100 MPa has been adopted popularly in East Asia for construction of tall buildings. Not only does the HSC improve the strength-to-weight ratio, reduce embodied energy, but also save extra floor space. Recently due to the rapid development of superfine materials such as micro-silica and superfine cement, as well as the matured filler technology [1,2], the concrete compressive strength can now be pushed up to 130 MPa. Using such a very high-strength concrete can also improve the lateral stiffness of tall buildings and limit the overall and inter-storey drift ratio to within the serviceability limit state. Therefore, it is indeed very attractive to the column construction of tall buildings. However, notwithstanding these merits, the adoption of such a high concrete strength is still rare in the construction industry. The use of lower concrete strength for column construction of tall buildings is under-utilising the construction materials and wasting available floor space that can possibly be saved.

One of the major reasons that inhibits the use of HSC is its brittleness [3-7], which needs to have substantial confinement to protect the concrete core from explosive failure. The traditional method of utilizing transverse steel in the form of closed hoops or ties for normal-strength reinforced concrete (RC) columns is not applicable in HSC columns, because the transverse reinforcement required for providing sufficient confinement against explosive failure will be too large to enable good placing quality of concrete. In order to have a breakthrough in the maximum limit that can be practically used in column construction, special type of confinement that can provide larger, more continuous and uniform confining pressure to concrete should be devised. One of the most ineffective reasons for adopting transverse reinforcement in RC columns is the 
concrete arching action, which decreases the effectively confined concrete area. In order to eliminate this action, a continuous concrete confinement in the form of steel tube has been advocated. Two composite structural forms of high-strength concrete-filled-steel-tubular (HSCFST) column that contains one (i.e. single-skinned) or two hollow steel tubes (i.e. double-skinned) for concrete confinement were put forward.

From structural point of view, these forms of composite column construction can provide larger axial strength [8-20], bending stiffness, moment capacity [10,21-24], better ductility [25,26,27] and excellent seismic performance [28-34]. The tubes are both longitudinal reinforcement and formwork, which saves the construction cycle time and cost. Due to composite action, the sizes of double-skinned CFST column can be up to $50 \%$ smaller than that of HSC columns with the same load-carrying capacity. The larger strength-to-weight ratio decreases the embodied energy level in the building structures. Furthermore, higher strength concrete is more durable than normal-strength concrete (NSC), therefore, it lengthens the design life of the buildings and reduces the construction and demolition waste generated. The double-skinned CFST columns are more structural efficient than another type of single-skinned CFST columns (one tube with in-filled concrete). It improves the strength-to-weight ratio by replacing the bulky central concrete with a lighter inner steel tube. It also provides a dry atmosphere within the inner steel tube, which is particularly useful to house sub-sea oil production facilities for offshore structures [32,35,36].

The steel tubes in the double-skinned CFST columns provide superior confining pressure to the in-filled concrete to enhance its strength and stiffness. However, the confinement performance during the initial elastic stage has not been fully developed due to the imperfect steel-concrete interface bonding [9,37] since steel dilates more than concrete under compression [38-41]. In order to maximize the confining performance of steel tubes in the early elastic stage, the authors have previously proposed to use external confinement in the form of steel rings to restrict the dilation of HSCFST columns for restoring an intact interface bonding $[42,43,44]$. The proposed method has been verified by a preliminary test programme on uni-axial compression performance of unconfined and ring-confined double-skinned CFST columns. It has been shown from the results that the rings provided effective lateral restraint points, and between the rings, the lateral dilation of columns is smaller than that of unconfined columns. Overall speaking, the Poisson's ratios of columns between ring levels were close to 0.2, except for the locations further away from the rings, which were about 0.3. It verified that the interface bonding have been substantially improved under the extra confinement effect provided by the steel rings. Previously, efforts have been spent on installing internal stiffeners and binding bars for achieving similar purpose [45-48]. However, it is worth noting that the welding of these internal stiffeners and binding bars are more difficult than that of the proposed external confinement, in particular for double-skinned HSCFST columns where the gap between steel skins is very limited.

Based on the test results, the authors have developed a theoretical model based on force equilibrium equations for evaluating the uni-axial load-carrying capacity of both unconfined and ring-confined double-skinned CFST columns. Nevertheless, the evaluation procedure was divided in to several steps and depends on hoop stress that is not readily available at early design stage. Therefore, an iterative process may be required to get the final load-carrying capacity of a design section. In order to simplify the evaluation process and to make the model more user friendly particularly at the design stage, the authors will in the paper investigate the major factors that affect the load-carrying capacity of ring-confined double-skinned HSCFST column through a parametric study. Based on the obtained results, a simplified equation relating the load-carrying capacity and solely geometry and material factors will be proposed. It is believed that the simplified equation can serve as a design aids for practical design of ring-confined double-skinned CFST columns. 


\section{DETAILS OF SPECIMENS}

To verify the effectiveness of the proposed external ring confinement on the improvement of interface bonding, strength and stiffness of double-skinned CFST columns, the authors has previously conducted a series of uni-axial compression test on 20 double-skinned CFST columns. The specimens were divided into four groups based on the provision of confinement, concrete cylinder strength and the hollow ratio $\chi$ (defined as $\chi=\frac{D_{i}}{D_{o}-2 t_{o}}$ ), where $D_{i}$ and $D_{o}$ are the diameters of the inner and outer tubes respectively, $t_{o}$ is the thickness of the outer tube: (1) Four double-skinned CFST columns of hollow ratio 0.56 and external steel rings of various spacing ( $5 t_{o}$, $10 t_{o}, 15 t_{o}$ and 20to); (2) Four double-skinned CFST columns of hollow ratio 0.72 and external steel rings of various spacing $\left(5 t_{o}, 10 t_{o}, 15 t_{o}\right.$ and 20t $\left.t_{o}\right)$; (3) One double-skinned CFST column of hollow ratio 0.56 but without external steel rings; (4) One double-skinned CFST column of hollow ratio of 0.72 but without external steel rings. In each of the two sets of specimens (i.e. $\chi=0.56$ and 0.72 ), concrete cylinder strength of 50 and $85 \mathrm{MPa}$ were adopted. The grade of both inner and outer steel tubes is S355 produced as per BS EN 10210-2:2006. For all tested specimens, the thickness of both inner and outer steel tubes is $5 \mathrm{~mm}$ and the diameter of outer steel tube is $168.3 \mathrm{~mm}$ (measured to the outer face). For columns of hollow ratios 0.56 and 0.72 , the diameters of inner tubes are 88.9 and $114.3 \mathrm{~mm}$ respectively (measured to the outer face). The total height of the specimens is $330 \mathrm{~mm}$ (aspect ratio of 2). Figure 1(a) shows the double-skinned normal-strength concrete-filled-steel-tubular (NSCFST) columns with hollow ratio of 0.56 and with external steel rings of various spacing $\left(5 t_{o}, 10 t_{o}, 15 t_{o}\right.$ and $\left.20 t_{o}\right)$. Figure 1(b) shows the double-skinned NSCFST columns with hollow ratio of 0.72 and with external steel rings of various spacing $\left(5 t_{o}, 10 t_{o}, 15 t_{o}\right.$ and $20 t_{o}$ ). Figure 1(c) shows the double-skinned NSCFST columns with hollow ratio of 0.56 and without external steel rings. Figure 1(d) shows the double-skinned NSCFST columns with hollow ratio of 0.72 and without external steel rings. Figure 1(e) shows the double-skinned HSCFST columns with hollow ratio of 0.56 and with external steel rings of various spacing $\left(5 t_{o}, 10 t_{o}, 15 t_{o}\right.$ and $20 t_{o}$ ). Figure 1(f) shows the double-skinned HSCFST with hollow ratio of 0.72 and with external steel rings of various spacing $\left(5 t_{o}, 10 t_{o}, 15 t_{o}\right.$ and $\left.20 t_{o}\right)$. Figure 1 (g) shows the double-skinned HSCFST columns with hollow ratio of 0.56 and without external steel rings. Figure 1(h) shows the double-skinned HSCFST columns with hollow ratio of 0.72 and without external steel rings. The section and material properties of the specimens are summarised in Table 1.

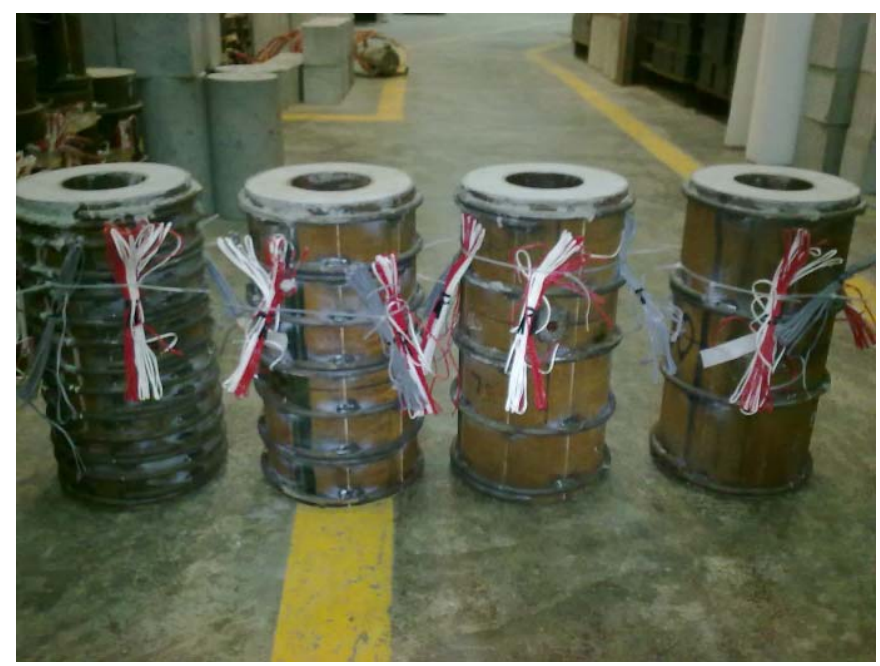

Figure 1(a) Double-skinned NSCFST columns with external steel rings $\left(s=5 t_{o}, 10 t_{o}, 15 t_{o}\right.$ and $\left.20 t_{o}\right)$ with Hollow Ratio of 0.56 


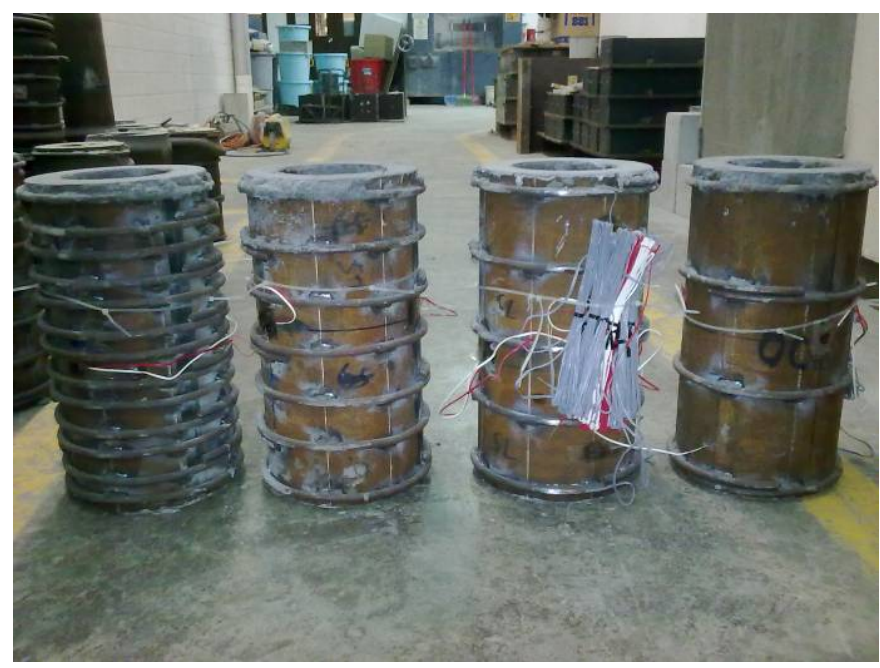

Figure 1(b) Double-skinned NSCFST columns with external steel rings $\left(s=5 t_{o}, 10 t_{o}, 15 t_{o}\right.$ and $\left.20 t_{o}\right)$ with Hollow Ratio of 0.72

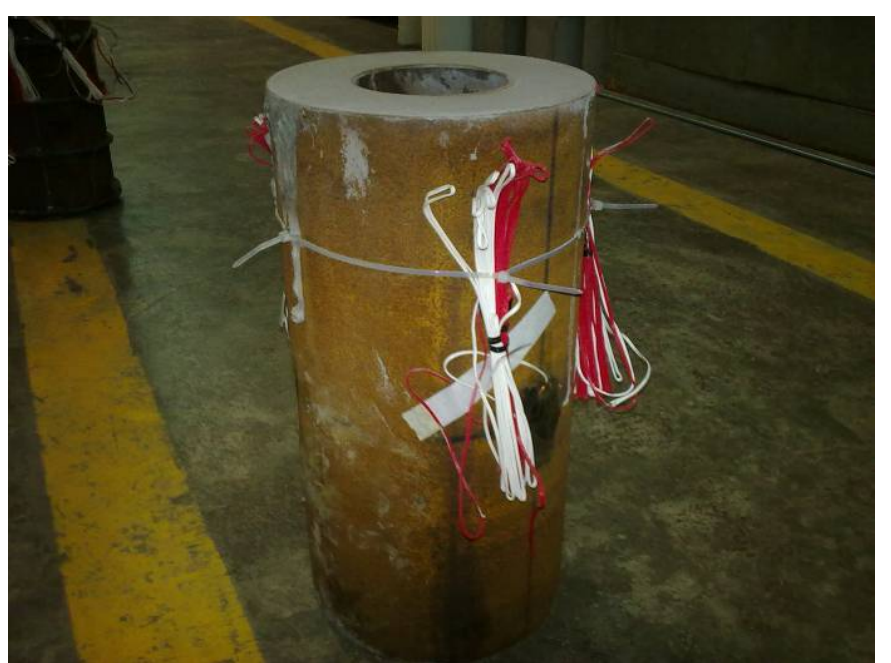

Figure 1(c) Double-skinned NSCFST columns without external steel ring with hollow ratio of 0.56

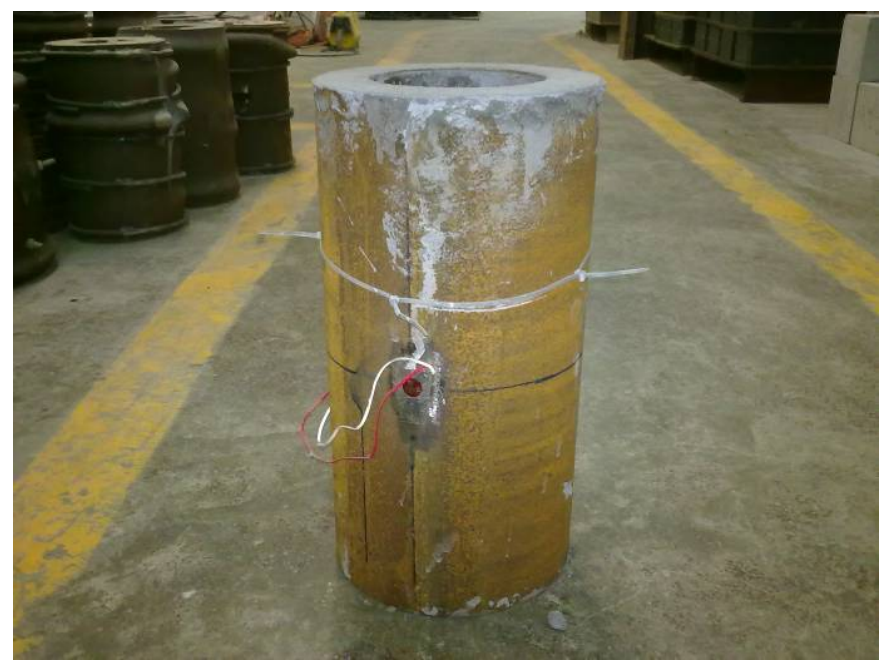

Figure 1(d) Double-skinned NSCFST columns without external steel ring with hollow ratio of 0.72 


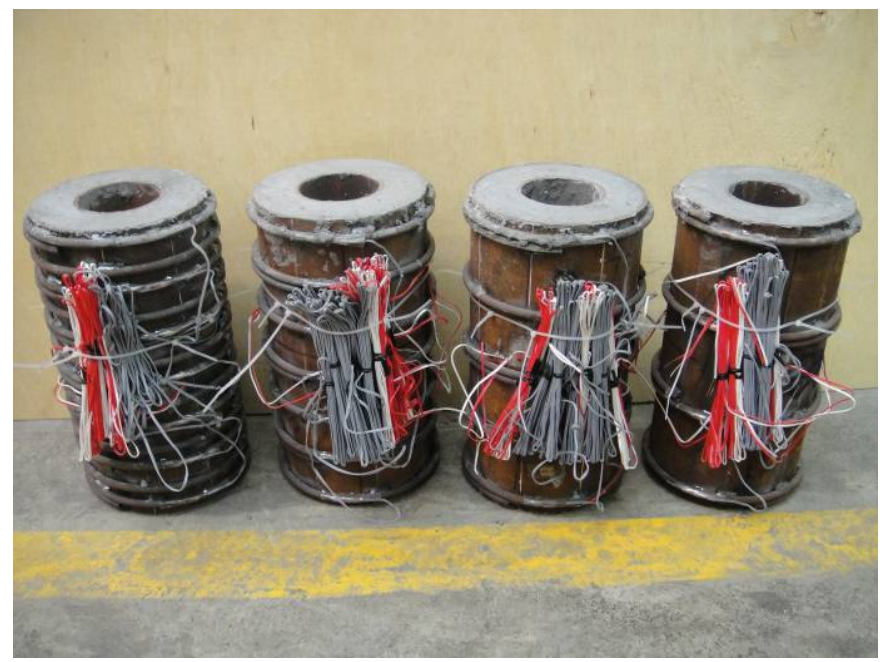

Figure 1(e) Double-skinned HSCFST columns with external steel rings $\left(s=5 t_{o}, 10 t_{o}, 15 t_{o}\right.$ and $\left.20 t_{o}\right)$ with hollow ratio of 0.56

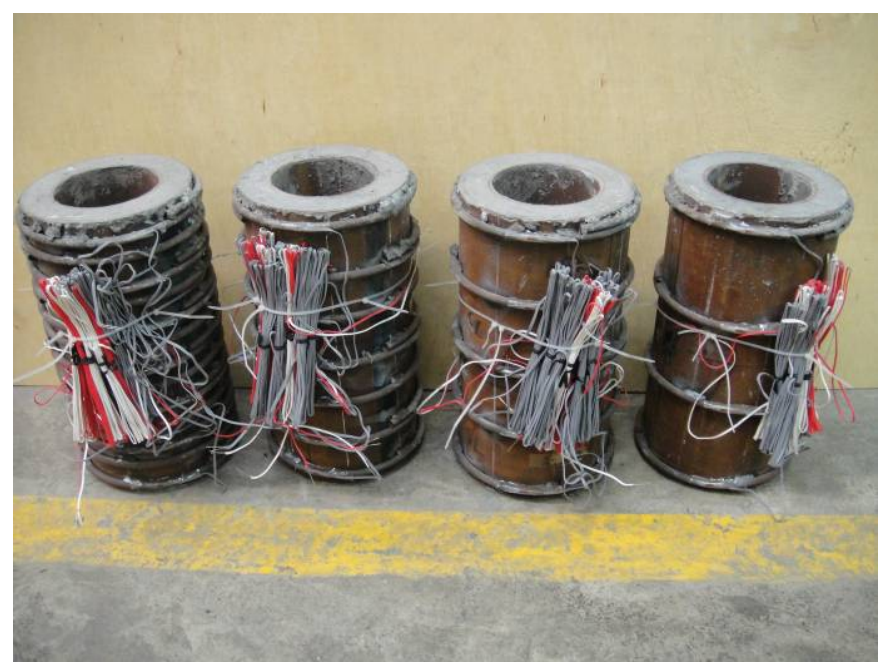

Figure 1(f) Double-skinned HSCFST columns with external steel rings $\left(s=5 t_{o}, 10 t_{o}, 15 t_{o}\right.$ and $\left.20 t_{o}\right)$ with hollow ratio of 0.72

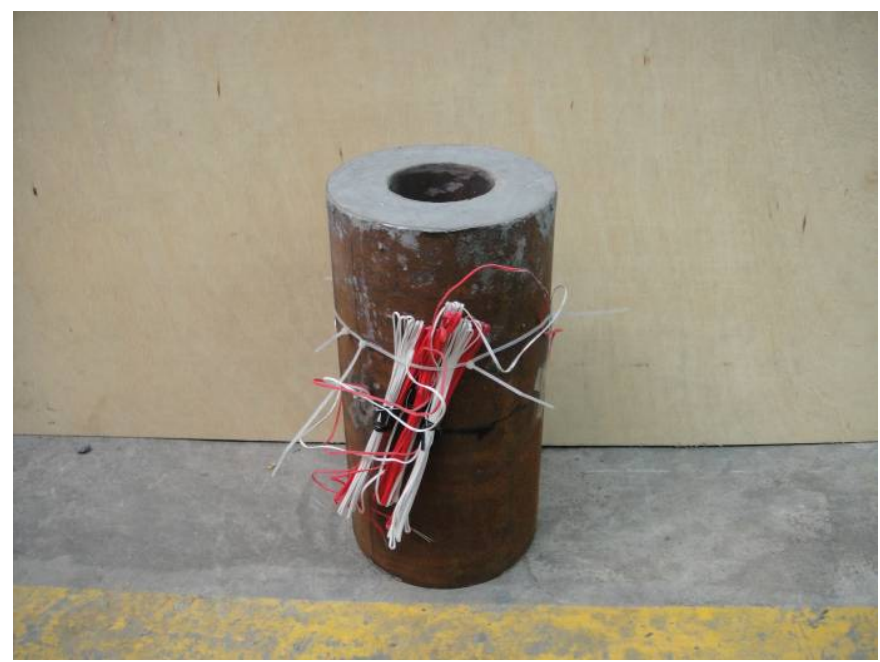

Figure 1(g) Double-skinned HSCFST columns without external steel ring with hollow ratio of 0.56 


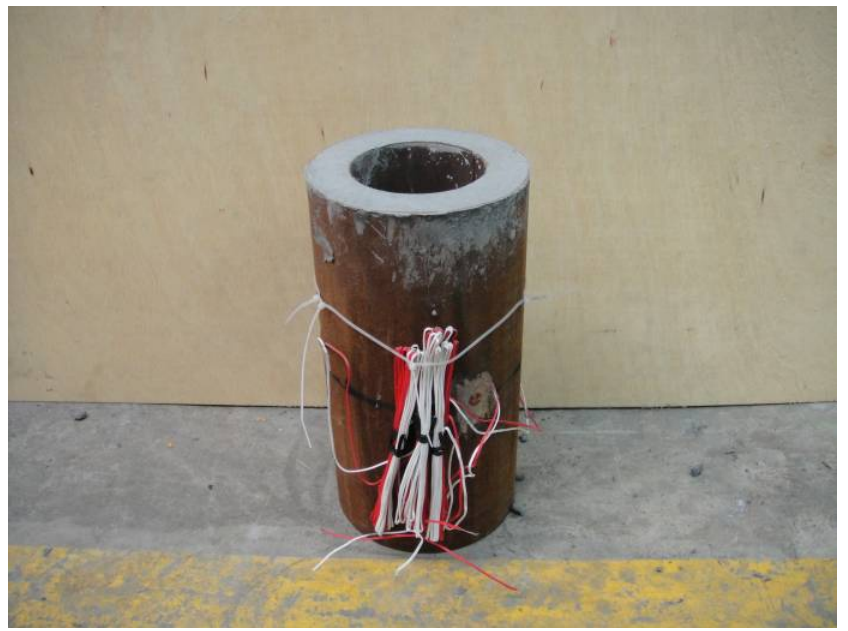

Figure 1(h) Double-skinned HSCFST columns without external steel ring with hollow ratio of 0.72

Table 1. Details of specimens and materials’ properties

\begin{tabular}{lllllllll}
\hline Specimen Label & $\begin{array}{c}D_{i} \\
(\mathrm{~mm})\end{array}$ & $\begin{array}{l}t_{i} \\
(\mathrm{~mm})\end{array}$ & $\begin{array}{l}f_{y, i} \\
(\mathrm{MPa})\end{array}$ & $\begin{array}{c}D_{o} \\
(\mathrm{~mm})\end{array}$ & $\begin{array}{l}t_{o} \\
(\mathrm{~mm})\end{array}$ & $\begin{array}{c}f_{y, o} \\
(\mathrm{MPa})\end{array}$ & $\begin{array}{c}f_{c}^{\prime} \\
(\mathrm{MPa})\end{array}$ & $\begin{array}{c}f_{y, R} \\
(\mathrm{MPa})\end{array}$ \\
\hline D-0.56-50-5 & 88.9 & 5 & 450 & 168.3 & 5 & 360 & 50 & 300 \\
D-0.56-50-10 & 88.9 & 5 & 450 & 168.3 & 5 & 360 & 50 & 300 \\
D-0.56-50-15 & 88.9 & 5 & 450 & 168.3 & 5 & 360 & 50 & 300 \\
D-0.56-50-20 & 88.9 & 5 & 450 & 168.3 & 5 & 360 & 50 & 300 \\
D-0.56-50-0 & 88.9 & 5 & 450 & 168.3 & 5 & 360 & 50 & N/A \\
D-0.56-85-5 & 88.9 & 5 & 450 & 168.3 & 5 & 360 & 85 & 300 \\
D-0.56-85-10 & 88.9 & 5 & 450 & 168.3 & 5 & 360 & 85 & 300 \\
D-0.56-85-15 & 88.9 & 5 & 450 & 168.3 & 5 & 360 & 85 & 300 \\
D-0.56-85-20 & 88.9 & 5 & 450 & 168.3 & 5 & 360 & 85 & 300 \\
D-0.56-85-0 & 88.9 & 5 & 450 & 168.3 & 5 & 360 & 85 & N/A \\
D-0.72-50-5 & 114.3 & 5 & 430 & 168.3 & 5 & 360 & 50 & 300 \\
D-0.72-50-10 & 114.3 & 5 & 430 & 168.3 & 5 & 360 & 50 & 300 \\
D-0.72-50-15 & 114.3 & 5 & 430 & 168.3 & 5 & 360 & 50 & 300 \\
D-0.72-50-20 & 114.3 & 5 & 430 & 168.3 & 5 & 360 & 50 & 300 \\
D-0.72-50-0 & 114.3 & 5 & 430 & 168.3 & 5 & 360 & 50 & N/A \\
D-0.72-85-5 & 114.3 & 5 & 430 & 168.3 & 5 & 360 & 85 & 300 \\
D-0.72-85-10 & 114.3 & 5 & 430 & 168.3 & 5 & 360 & 85 & 300 \\
D-0.72-85-15 & 114.3 & 5 & 430 & 168.3 & 5 & 360 & 85 & 300 \\
D-0.72-85-20 & 114.3 & 5 & 430 & 168.3 & 5 & 360 & 85 & 300 \\
D-0.72-85-0 & 114.3 & 5 & 430 & 168.3 & 5 & 360 & 85 & N/A \\
\hline
\end{tabular}

In all specimens, the external steel rings were mild steel round bars of $8 \mathrm{~mm}$ diameter and the yield strength is $f_{R}=300 \mathrm{MPa}$. The rings were welded to the outer tubes at different spacing and the lap length was ten times the diameter of the steel bar $(80 \mathrm{~mm})$. Each ring was welded to the outer tube at eight locations with a central angle of $45^{\circ}$ separated from each other. Figures 2 and 3 show the test setup and the details of the specimens.

A naming system consisting of one letter and three numbers has been used to represent the specimens. For instance, 'D-0.72-50-5' represents a double-skinned CFST column (indicated by the first letter "D"), a hollow ratio of 0.72 (indicated by the first number " 0.72 "), a concrete cylinder strength of about $50 \mathrm{MPa}$ on the testing day (indicated by the second number " 50 ") and lastly five times the thickness of the outer steel tube as the ring spacing (indicated by the last number “5”). Alternatively, 'D-0.56-85-0' represents a double-skinned CFST column (indicated by the first letter " $D$ ") with a hollow ratio of 0.56 (indicated by the first number " 0.56 "), a concrete cylinder strength of about $85 \mathrm{MPa}$ on the testing day (indicated by the second number "85"), and lastly no external steel ring (i.e. zero spacing indicated by the last number “0”). 


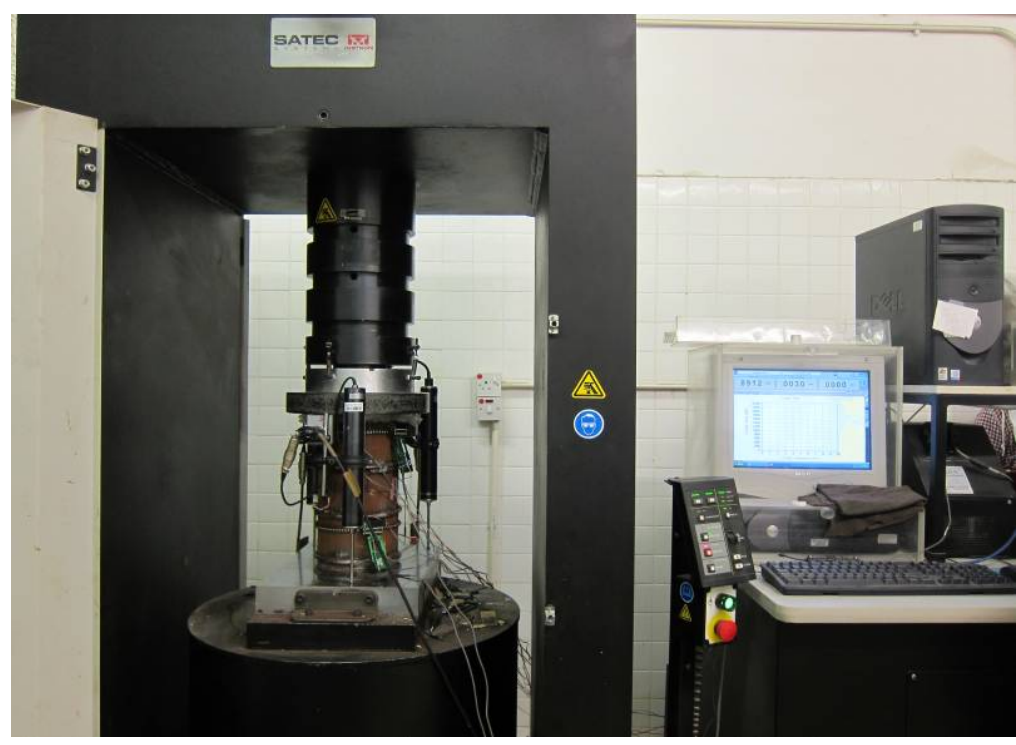

Figure 2 Test setup

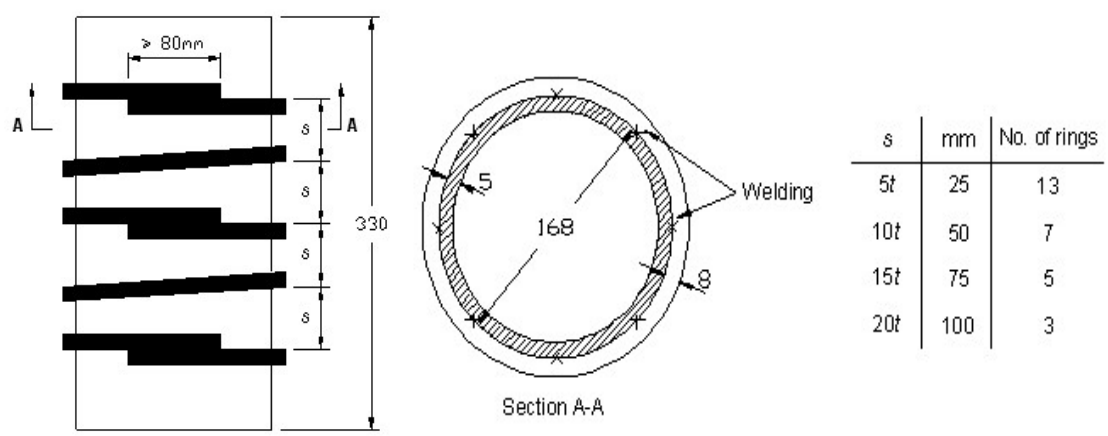

Figure 3 Details of external steel rings of specimens

\section{SIMPLIFIED DESIGN MODEL FOR CONFINED DOUBLE-SKINNED CFST COLUMNS}

\subsection{Theoretical Equations for Confined Double-skinned CFST Columns}

There were a lot of researches conducted on the theoretical models of double-skinned HSCFST columns [49-52]. However, all of these models were developed based on unconfined double-skinned CFST columns. Furthermore, the design guidelines specified in Eurocode 4 [53] were also only applicable to unconfined CFST columns. If those models and guidelines are used for design of confined double-skinned CFST columns, the uni-axial load-carrying capacity will be significantly underestimated. To this, the authors have previously developed a theoretical model based on force equilibrium method to predict the uni-axial load carrying capacity of ring-confined double-skinned CFST columns. The validity of the theoretical model has been verified by comparing the theoretical results with the experimental results obtained previously by the authors and other researchers $[9,13,22,51,54]$. Good agreement was obtained.

The following briefly summarises the theoretical formulas for evaluating the axial capacity of the double-skinned CFST columns: 
$N_{p}=f_{i} A_{i}+f_{o} A_{o}+f_{c c} A_{c c}$

where $N_{p}$ in Eq. 1 represents the predicted axial load capacity of double-skinned CFST column with/without external confinement. In Eq. $1, f_{i}$ and $f_{o}$ are the axial stresses in the inner and outer tubes respectively under bi-axial stress state; $f_{c c}$ is the axial stress in the core concrete under the confining pressure $f_{r}$. These parameters are given by the following equations:

$f_{o}^{2}-f_{o} \sigma_{\theta, o}+\sigma_{\theta, o}{ }^{2}=f_{y, o}{ }^{2}$

$f_{i}^{2}-f_{i} \sigma_{\theta, i}+\sigma_{\theta, i}{ }^{2}=f_{y, i}{ }^{2}$

$f_{c c}=f_{c}{ }^{\prime}+4.1 f_{r}$

where $f_{y, o}, f_{y, i}$ are the uni-axial yield strength of the steel tubes, $f_{r}$ is the confining pressure and $f_{c c}$ is the confined concrete strength [55]. The hoop stress $\sigma_{\theta, o}$ of the outer tube at ultimate strength is taken as the formulas proposed by Hatzigeorgiou [56] in Eq. 3:

$$
\begin{aligned}
& \sigma_{\theta, o}=\alpha_{\theta} f_{y, o} \\
& \alpha_{\theta}=\exp \left(\ln \left(\frac{D_{0}}{t_{0}}\right)+\ln \left(f_{y, o}\right)-11\right) \leq 1
\end{aligned}
$$

The confining pressure $f_{r}$ for ring-confined and unconfined specimens is shown in Eq. $4 \mathrm{a}$ and $4 \mathrm{~b}$ respectively.

$$
\begin{aligned}
f_{r} & =-\frac{2 t_{o} h \sigma_{\theta, o}-2 n A_{R} \sigma_{R}}{\left(D_{o}-2 t_{o}\right) h} \\
f_{r} & =-\frac{2 t_{o} \sigma_{\theta, o}}{\left(D_{o}-2 t_{o}\right)}
\end{aligned}
$$

where $\sigma_{\theta, o}$ is the hoop tensile stress developed in the outer tube; $\sigma_{R}$ is the tensile stress acting in the external rings; $A_{R}$ is the cross-section area of each steel ring; $D_{o}$ and $t_{o}$ represent the diameter and thickness of the outer steel tube; $h$ stands for the total height of the column; $n$ is the number of the external steel rings welded on the specimen.

\subsection{Simplified Formulas for Confined Double-skinned CFST Columns}

One of the difficulties of applying the above equation in design stage is that the whole calculation process is split into different parts and complicated equations such as those for the hoop stress and the Von Mises Criterion have to be gone through each time. For the sake of design purpose, it is better to have an equation depending on solely the geometry and material factors that are readily available in early design stage. Hence, based on the theoretical equations presented above, a parametric study on the effects of various geometry and material factors on the uni-axial load-carrying capacity of double-skinned CFST columns will be conducted herein. The cross-sections adopted are circular double-skinned CFST columns of outer diameter $1 \mathrm{~m}$. In the parametric study, the following parameters have been varied:

(1) The concrete cylinder strength $\left(f_{c}^{\prime}\right)$ was varied from 20 to $80 \mathrm{MPa}$ to cover typical double-skinned CFST columns cast with normal- and high-strength concrete. 
(2) The hollow ratio $(\chi)$ was varied from 0.3 to 0.7 in this study to cover typical double-skinned CFST column that can be constructed practically.

(3) The diameter-to-thickness ratios of outer $\left(D_{o} / t_{o}\right)$ and inner $\left(D_{i} / t_{i}\right)$ steel tubes were varied from 40 to 100 .

(4) The yield strength of inner $\left(f_{y, i}\right)$ and outer steel tube $\left(f_{y, o}\right)$ was taken as 275,355 or $460 \mathrm{MPa}$. The same yield strength was adopted for the outer and inner tubes because it is usually the practice in real design and construction.

(5) The volumetric ratio of external rings to concrete $\left(\rho_{R}\right)$, which is defined as the ratio between the volumes of external rings to the in-filled concrete, was varied from 0 (i.e. unconfined) to $10 \%$.

(6) Mild steel is adopted as the external rings, the yield strength of which is taken as 235 or 275 MPa.

\subsubsection{Confining pressure provided by outer tube $\left(f_{r, t u b e}\right)$}

From the previously proposed theoretical model, it is evident that the confining pressure $\left(f_{r}\right)$ provided by the steel tube and the external rings to the concrete is the most crucial parameter to predict the uni-axial load-carrying capacity. In this study, it is proposed to investigate the relationship of $f_{r}$ with other parameters based on the obtained results. The investigation is separated into two parts: (1) Confining pressure provided by the steel tube $\left(f_{r, \text { tube }}\right.$ ); (2) Confining pressure provided by the rings $\left(f_{r, \text { ring }}\right)$. Firstly, the confining pressure provided by the outer steel tube was plotted against the diameter-to-thickness ratio $D_{o} / t_{o}$ for different yield strength of the outer tube as shown in Figure 4. The $y$-axis represents $f_{r \text {,tube }}$ given by Eqs. (3) and (4b). The $x$-axis represents the diameter-to-thickness ratios of the outer steel tubes. From the figure, it is found that $f_{r, t u b e}$ is insensitive to the diameter-to-thickness ratio $D_{o} / t_{o}$ for a particular yield strength. Therefore, in this study, it is proposed to use a constant value for $f_{r, t u b e}$, which is taken as the lower bound value obtained in the parametric study for each of the yield strength. For the sake of practical design purpose, the adopted lower bound values of $f_{r \text {,tube }}$ have been plotted against the yield strength of the outer steel tube $f_{y, o}$ in Figure 5. From the figure, it is found that these two parameters can be correlated very well using linear equation, which is written in Eq. (5):

$f_{r, t u b e}=0.025 f_{y, o}-4.5$

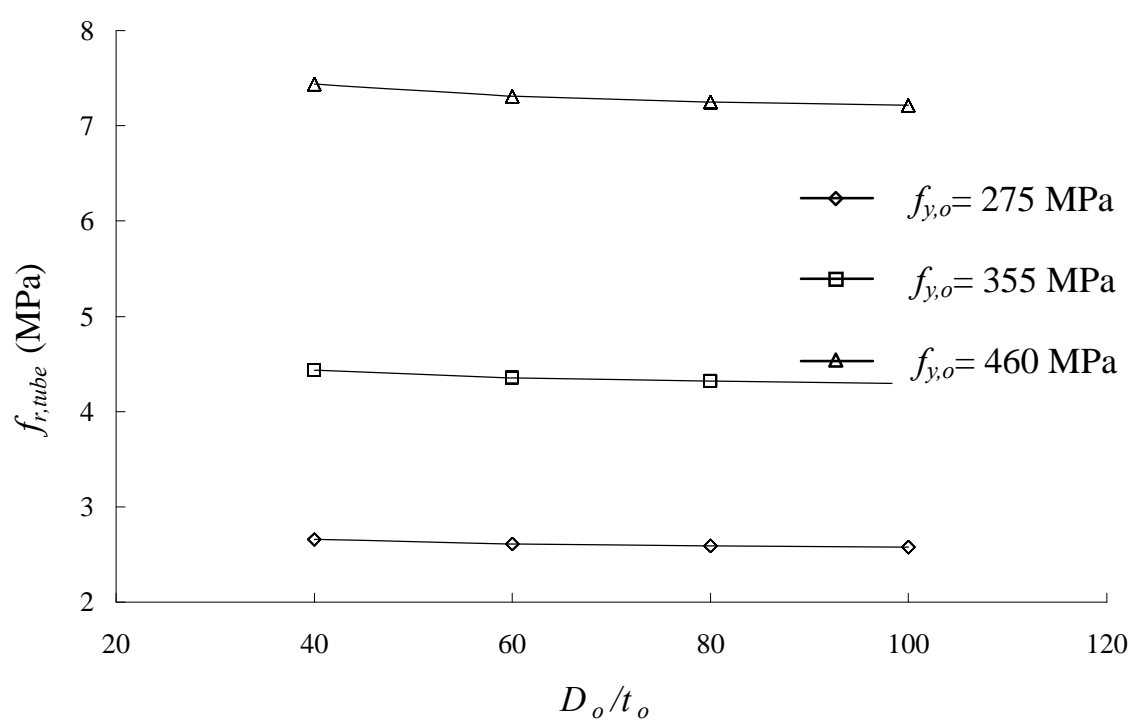

Figure 4 Confining pressure $f_{r, \text { tube }}$ against diameter-to-thickness ratio $D_{o} / t_{o}$ 


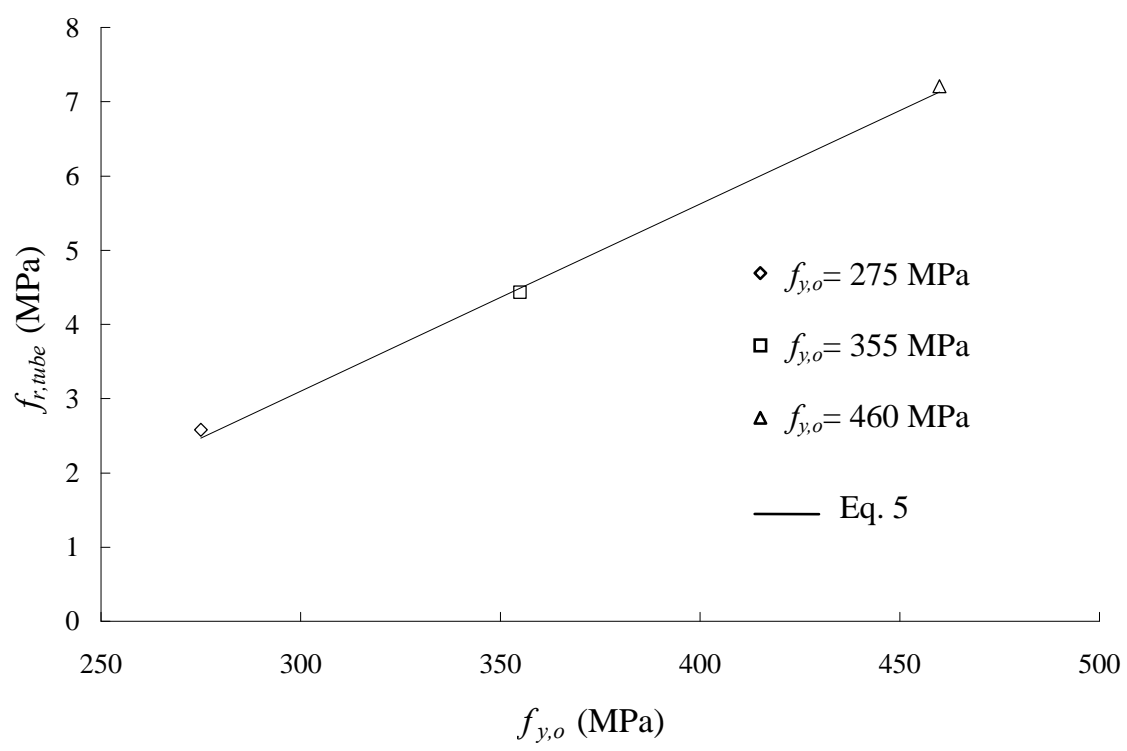

Figure 5 Confining pressure $f_{r \text {,tube }}$ against yield strength of outer steel tube $f_{y, o}$

\subsubsection{Confining pressure provided by external rings $\left(f_{\text {r,ring }}\right)$}

On the other hand, the relationship of confining pressure provided by external ring $\left(f_{r, \text { ring }}\right)$ with other studied parameter needs to be determined in order to find out the total confining pressure $f_{r}$ for a given double-skinned CFST column section. A new non-dimensional parameter of volumetric ratio of external confinement $\rho_{R}$ is hence proposed, which is defined as the volume of steel rings $\left(V_{R}\right)$ to the volume of concrete $\left(V_{c}\right)$ in the double-skinned CFST columns. By this definition, the following mathematical expression for $\rho_{R}$ can be derived:

$\rho_{R}=\frac{V_{R}}{V_{c}}=\frac{n \pi\left(D_{o}+2 r_{R}\right) A_{R}}{h \pi\left[\left(\frac{D_{o}-2 t_{o}}{2}\right)^{2}-\left(\frac{D_{i}}{2}\right)^{2}\right]}=\frac{4}{1-\chi^{2}} \frac{\left(D_{o}+2 r_{R}\right) A_{R}}{s\left(D_{o}-2 t_{o}\right)^{2}}$

The confining pressure provided by the rings can be expressed in Eq. (7a) by considering the force equilibrium:

$f_{r, \text { ring }}=\frac{2 n A_{R} f_{y, R}}{\left(D_{o}-2 t_{o}\right) h}=\frac{f_{y, R}}{2} \frac{V_{R}}{V_{c}}\left(1-\chi^{2}\right) \frac{\left(D_{o} / t_{o}\right)-2}{\left(D_{o} / t_{o}\right)+2\left(r_{R} / t_{o}\right)}=\frac{f_{y, R}}{2} \rho_{R}\left(1-\chi^{2}\right) G$

where $G$ is a geometric factor. It should be noted that in Eq. 7a, a uniform confining pressure is assumed to be produced by the rings on the steel tube and the concrete core. This can be justified as the rings spacing are small when compared with the diameter of the column. From Eq. 7a, it is seen that the geometric factor $G$ depends on the diameter-to-thickness of the outer tube $\left(D_{o} / t_{o}\right)$, as well as the ratio of radius of rings $\left(r_{R}\right)$ to thickness of outer tube $\left(t_{o}\right)$. Since $\left(r_{R} / t_{o}\right)$ is much smaller than $\left(D_{o} / t_{o}\right)$, and that $r_{R}$ is similar to $t_{o}$, it can be deduced that $G$ can be correlated reasonably well to just $\left(D_{o} / t_{o}\right)$. Thus, the variation of $G$ has been plotted against $\left(D_{o} / t_{o}\right)$ for from $40-100$ in Figure 6 . From Figure 6, it is apparent that the variation of $G$ against $\left(D_{o} / t_{o}\right)$ varies within a narrow range from 0.90 to 0.96. For the purpose of practical design of CFST columns, a lower bound value of $G=0.90$ is adopted. Hence, substituting $G=0.90$ into Eq. 7a, the following equation is proposed for the confining pressure provided by the external rings: 


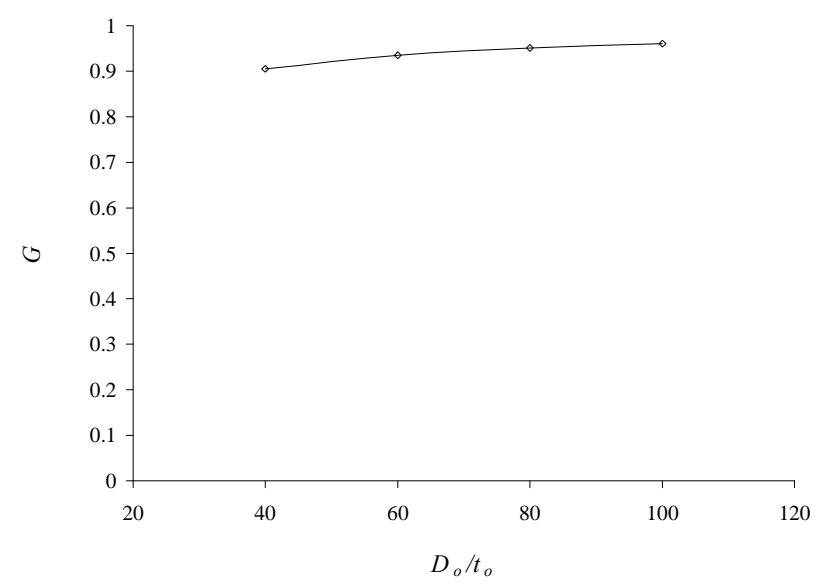

Figure 6 Minimum value of $G$ against diameter-to-thickness $D_{o} / t_{o}$

$f_{r, \text { ring }}=0.45 f_{y, R} \rho_{R}\left(1-\chi^{2}\right)$

The total confining pressure $\left(f_{r}\right)$ can be obtained by adding up Eqs. 5 and 7b, which is given by Eq. 7c:

$f_{r}=f_{r, \text { tube }}+f_{r, \text { ring }}=\left(0.025 f_{y, o}-4.5\right)+0.45 f_{y, R} \rho_{R}\left(1-\chi^{2}\right)$

To verify the validity of the simplified equation for $f_{r}$ as shown in Eq. 7c, the values of $f_{r}$ calculated in the proposed model by Eqs. 3a, 4a and 4b are plotted against those calculated by Eq. 7c in Figure 7. It can be observed from the graph that both values are very close to each other.

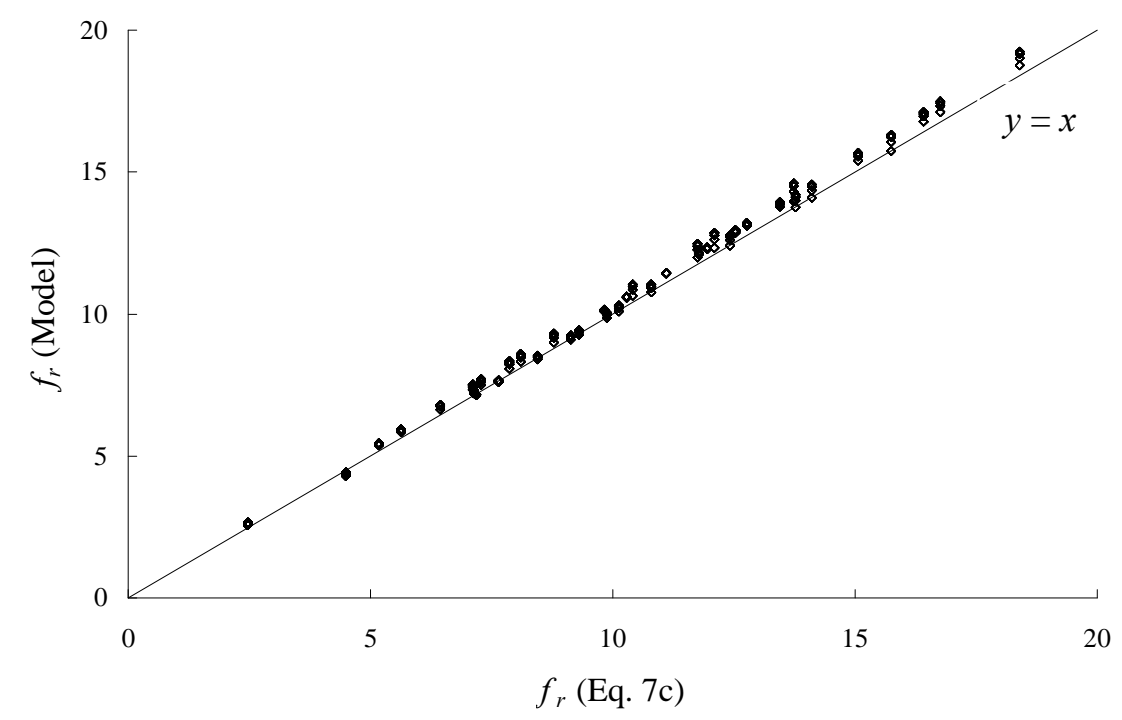

Figure 7 Comparison between the results obtained by model and Eq. 7c

\subsubsection{Axial yield strength of the outer $\left(f_{o}\right)$ tube and inner $\left(f_{i}\right)$ tube under bi-axial state}

Apart from the confining the pressure $\left(f_{r}\right)$, it is essential to determine the yield stresses of both outer and inner tubes in order to assess the uni-axial load-carrying capacity of double-skinned CFST columns. For the outer tube, it is evident from Eqs. 2a, 3a and 4 that the major factors affecting 
the yield stress of the steel tube under bi-axial state $\left(f_{o}\right)$ are the confining pressure on the steel tube $\left(f_{r, t u b e}\right)$, diameter-to-thickness ratio $\left(D_{o} / t_{o}\right)$ and the uni-axial yield strength $\left(f_{y, o}\right)$. Since $f_{r, t u b e}$ depends on $D_{o} / t_{o}$, it can be said that the major factors affecting the non-dimensional axial yield strength of the outer tube $\left(f_{o} / f_{y, o}\right)$ are only $\left(D_{o} / t_{o}\right)$ and $f_{y, o}$. From the results obtained in the parametric study, value of $\left(f_{o} / f_{y, o}\right)$ have been plotted against the $\left(D_{o} / t_{o}\right)$ in Figures 8(a) and 8(b). It is found from graphs that the value of $\left(f_{o} / f_{y, o}\right)$ decreases as $D_{o} / t_{o}$ increases for different yield strength and decreases as $f_{y, o}$ increases. An empirical formula is then set up correlating $\left(f_{o} / f_{y, o}\right)$ to $\left(D_{o} / t_{o}\right), f_{y, o}$ and is written in Eq. 8.

$$
\frac{f_{o}}{f_{y, o}}=1-\left[1.6 \times 10^{-7}\left(\frac{D_{\mathrm{o}}}{t_{\mathrm{o}}}\right)^{2}-1.4 \times 10^{-6}\left(\frac{D_{\mathrm{o}}}{t_{\mathrm{o}}}\right)\right] f_{y, o}
$$

For the axial yield strength of the inner tube $\left(f_{i}\right)$, it is noted from Eqs. 2b, 3b and 4 that the major factors affecting $f_{i}$ are also the confining pressure $\left(f_{r, t u b e}\right)$, diameter-to-thickness ratios of the outer tube $\left(D_{o} / t_{o}\right)$ and inner tube $\left(D_{i} / t_{i}\right)$. By the same token, the non-dimensional axial strength to yield strength ratio of the inner $\left(f_{i} / f_{y, i}\right)$ is plotted against $\left(D_{i} / t_{i}\right)$ for various steel yield strength in Figures 9(a) $\left(D_{o} / t_{o}=40\right), 9(\mathrm{~b})\left(D_{o} / t_{o}=60\right), 9(\mathrm{c})\left(D_{o} / t_{o}=80\right)$ and 9(d) $\left(D_{o} / t_{o}=100\right)$. Unlike the outer steel tube, it is evident from Figure 9 that the value of $f_{i}$ under bi-axial state is less significantly affected than that in outer tube $f_{o}$. The values of $\left(f_{i} / f_{y, i}\right)$ were varying from 1.08 to 1.15 . For the purpose of practical design of CFST columns, a lower bound value of 1.08 is adopted. An empirical formula is then set up for $\left(f_{i} / f_{y, i}\right)$ and is shown in Eq. 9.

$$
\frac{f_{i}}{f_{y, i}}=1.08
$$

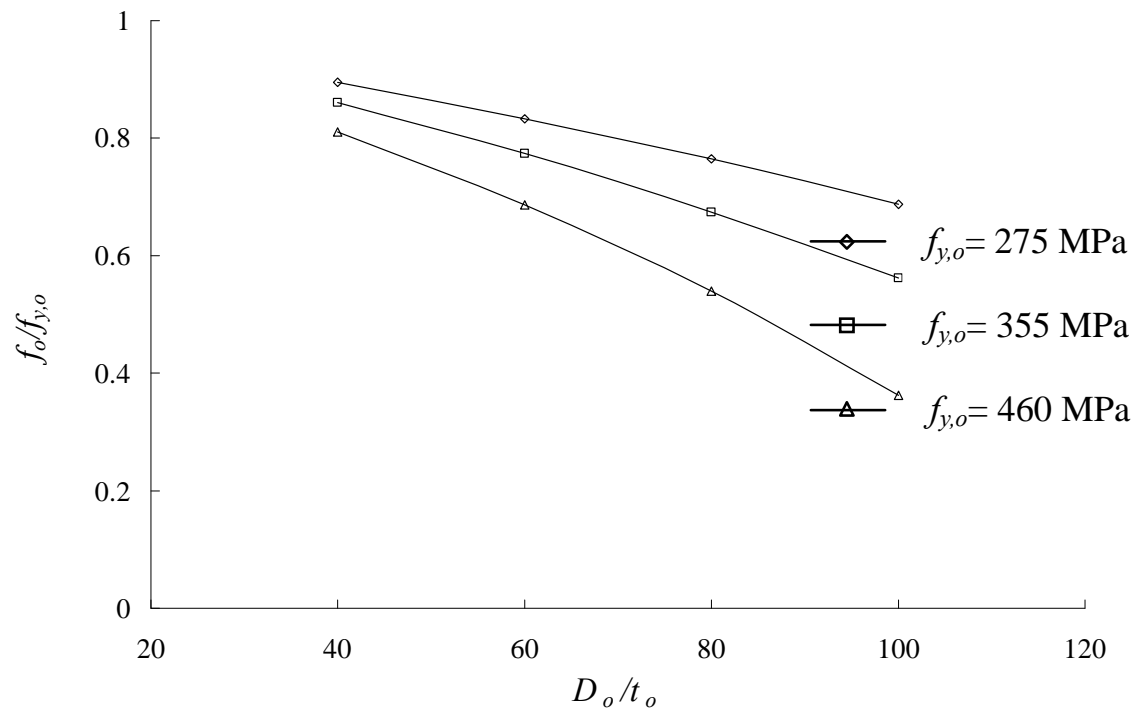

Figure 8(a) Axial-to-yield stress ratio (Outer Tube) against diameter-to-thickness ratio $D_{o} / t_{o}$ 


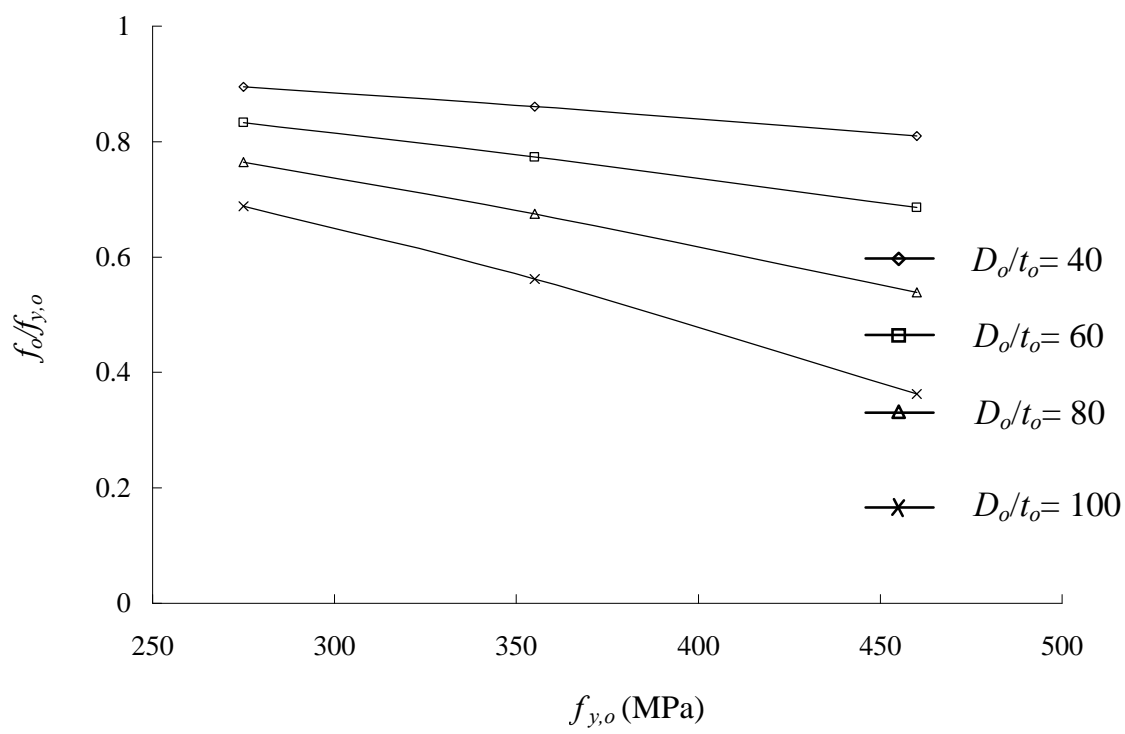

Figure 8(b) Axial-to-yield stress ratio (outer tube) against yield strength of outer tube $f_{y, o}$

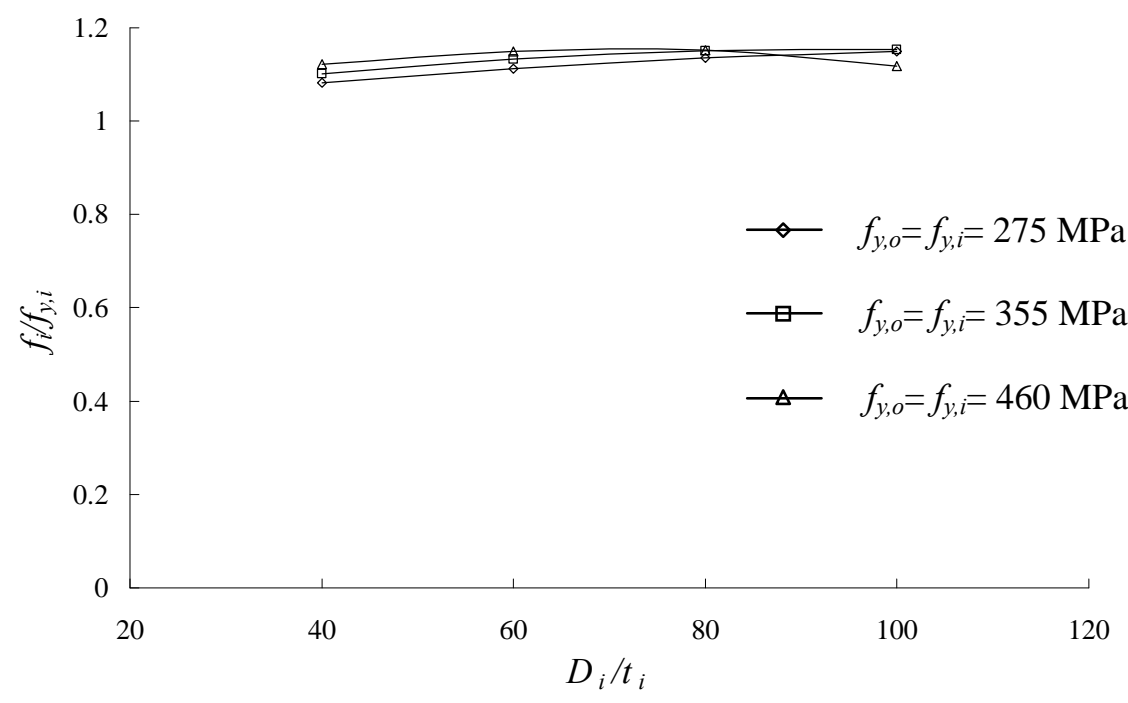

Figure 9(a) Axial-to-yield stress ratio (Inner tube) against diameter-to-thickness ratio of inner tube $D_{i} / t_{i}$ for diameter-to-thickness ratio of outer tube $D_{o} / t_{o}=40$ 


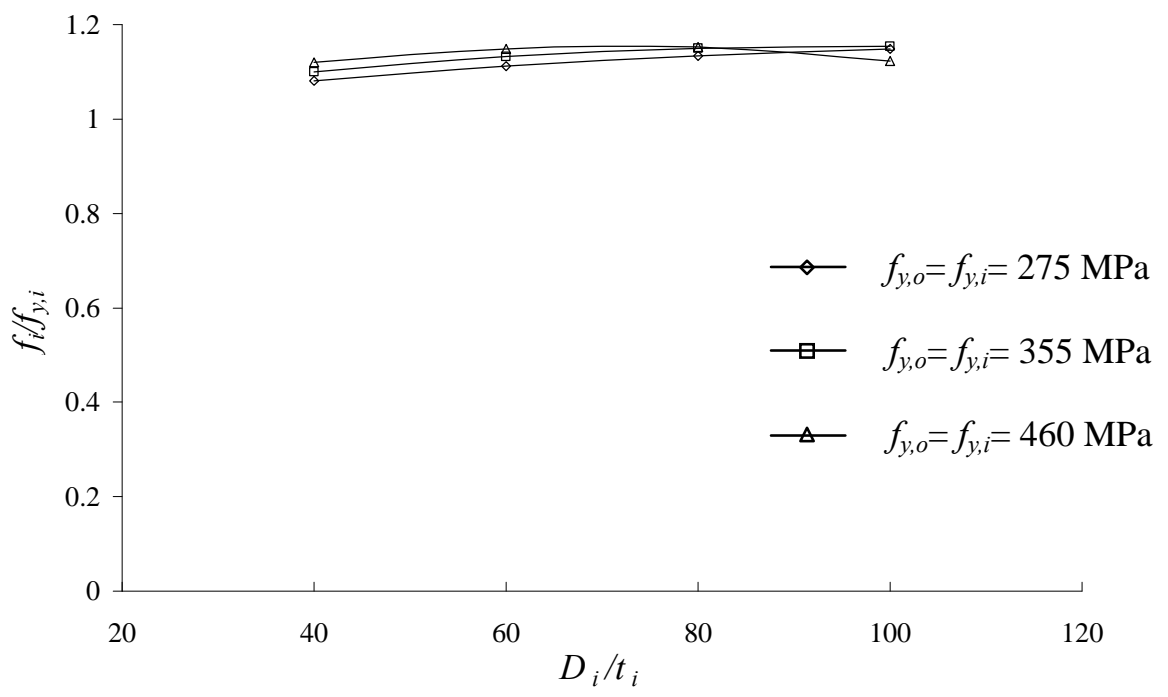

Figure 9(b) Axial-to-yield stress ratio (inner tube) against diameter-to-thickness ratio of inner tube $D_{i} / t_{i}$ for diameter-to-thickness ratio of outer tube $D_{o} / t_{o}=60$

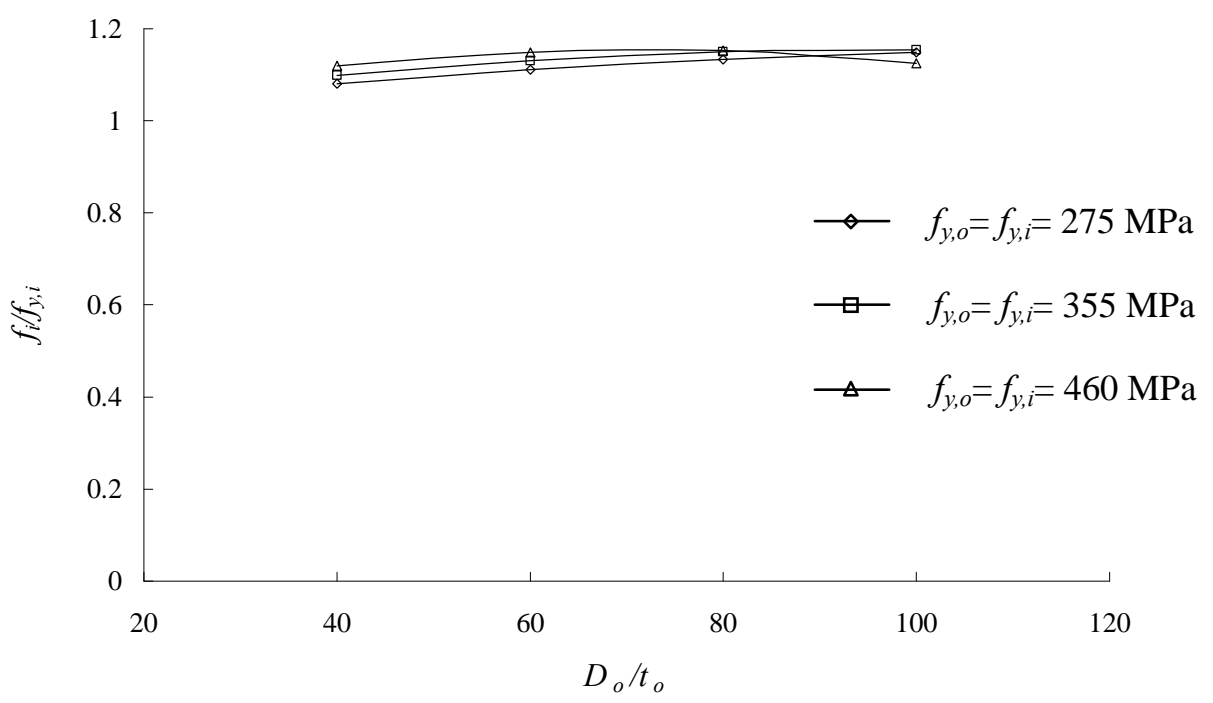

Figure 9(c) Axial-to-yield stress ratio (Inner tube) against diameter-to-thickness ratio of inner tube $D_{i} / t_{i}$ for diameter-to-thickness ratio of outer tube $D_{o} / t_{o}=80$ 


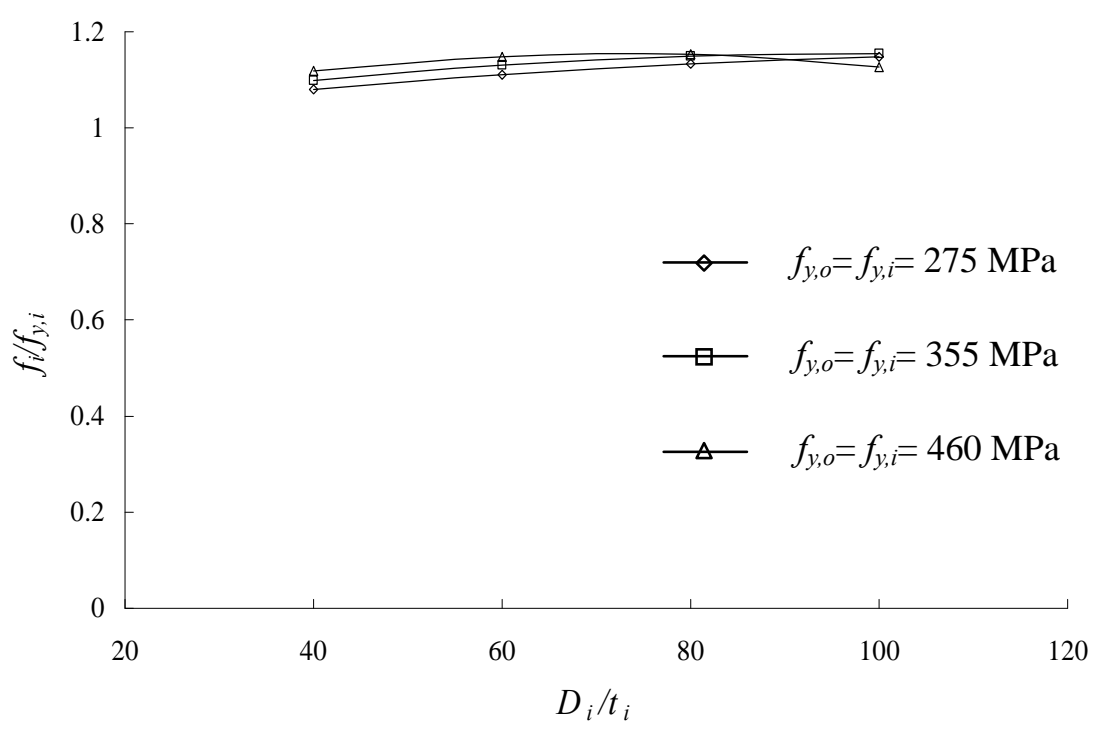

Figure 9(d) Axial-to-yield stress ratio (Inner tube) against diameter-to-thickness ratio of inner tube $D_{i} / t_{i}$ for diameter-to-thickness ratio of outer tube

\subsubsection{Confined concrete strength ( $\left.f_{c c}\right)$ under confinement}

As seen from Eq. 2c, the most critical factor affecting the confined concrete strength $\left(f_{c c}\right)$ is the confining pressure $\left(f_{r}\right)$. Substituting the empirical equation proposed for the confining pressure $f_{r}$ as shown in Eq. 7c into Eq. 2c, the value of $f_{c c}$ can be obtained.

\subsubsection{Simplified equation for predicting uni-axial strength}

From the first principle, the following equation can be adopted to evaluate the uni-axial strength of double-skinned CFST columns:

$N_{p}{ }^{\prime}=f_{c c} A_{c}+f_{o} A_{s o}+f_{i} A_{s i}$

where $N_{P}{ }^{\prime}$ is the predicted uni-axial strength of double-skinned CFST column by the simplified equation, $A_{c}, A_{s o}$ and $A_{s i}$ are the cross-section areas of the concrete, outer steel tube and inner steel tube respectively. Substituting Eqs. 2c, 8 and 9 into Eq. 10, the following equation is obtained:

$N_{p}^{\prime}=A f_{c}^{\prime} A_{c}+B f_{y, o} A_{s o}+C f_{y, i} A_{s i}$

where $A=\left(1+4.1 \frac{f_{r}}{f_{c}^{\prime}}\right), \quad B=1-\left[1.6 \times 10^{-7}\left(\frac{D_{0}}{t_{\mathrm{o}}}\right)^{2}-1.4 \times 10^{-6}\left(\frac{D_{\mathrm{o}}}{t_{\mathrm{o}}}\right)\right] f_{y, o}$ and $C=1.08$. It is worth noting that since the strength enhancement in the inner steel tube due to confinement effect is relatively smaller (see Eq. 9), and that the cross-section area of the inner tube is considerably smaller than those of concrete and outer tube, it is believed that the influence of factor $C$ is insignificant to the final result of the uni-axial load-carrying capacity $N_{p}{ }^{\prime}$. Hence, the authors propose to simply take the value of $C$ as unity in all cases and the final form of equation is shown as follows: 
$N_{p}^{\prime}=A f_{c}^{\prime} A_{c}+B f_{y, o} A_{s o}+f_{y, i} A_{s i}$

The formula shown in Eq. 12 will be very useful to the structural designers for a prescribed uni-axial load-carrying capacity of doubled-skinned CFST columns. It is because Eq. 12 expresses the uni-axial load-carrying capacity in terms of some basic material and geometry parameters that can be obtained readily at early design stage. The formula will thus provide a straightforward method for designing the cross-section of double-skinned CFST column based on prescribed uni-axial strength.

The accuracy of the simplified formula as shown in Eq. 12 is checked by plotting the uni-axial strength calculated by Eq. 12 against that by the proposed model as shown in Eqs. 1 to 4 for all trial sections' results obtained in the parametric study (total specimen numbers > 3,000). The comparison is shown in Figure 10. The obtained average value and standard deviation of $N_{p} / N_{p}{ }^{\prime}$ is 0.990 and 0.023 respectively, which suggests that the proposed simplified formula given in Eq. 12 is applicable for predicting and designing the uni-axial strength of double-skinned CFST columns with a wide range of geometric and material parameters.

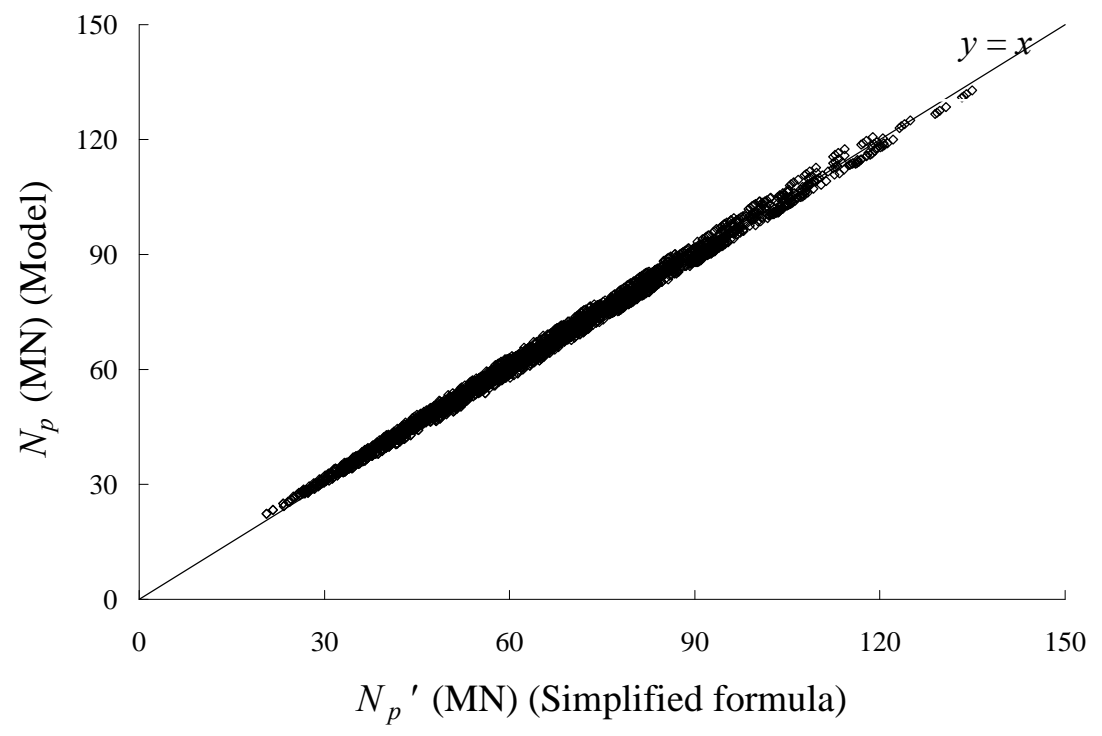

Figure 10. Comparison between the Results Obtained by Model and Simplified Formula

\section{CONCLUSIONS}

A new method of providing external confinement to restrict the lateral dilation of double-skinned CFST columns has been proposed and verified previously by uni-axial compression tests. A theoretical model has been developed for uni-axial load-carrying capacity for CFST columns that takes into account the confining effects provided by steel rings and steel tube. The validity of the proposed model has been verified by comparing with the experimental results obtained by the authors and other researchers on both confined and unconfined double-skinned CFST columns.

Using the developed model, a parametric study has been carried out to investigate the effects of various geometry and material factors on the uni-axial load-carrying capacity of confined double-skinned CFST columns. It has been identified that the confining pressure $f_{r}$ is the major factor affecting the uni-axial strength. To facilitate practical design procedure without the need of going through the detailed calculation as per the proposed model, it is decided to establish empirical equation correlating the confining pressure $f_{r}$ to various geometry and material factors. 
By using the proposed empirical equation for $f_{r}$, the authors has eventually come up with a very simple formula capable of evaluating the uni-axial strength of confined double-skinned CFST columns based on only readily available design data, such as cross-section areas of concrete and steel tubes, as well as concrete cylinder and steel tube yield strength. The uni-axial strength predicted by the simplified equation has been compared with those obtained from the theoretical model, and excellent agreement was obtained. It is believed that the simplified equation can provide the structural designer a rapid and accurate design formula for estimating the uni-axial strength of double-skinned CFST column at early design stage based only on geometry and material factors.

\section{ACKNOWLEDGEMENT}

The work described in this paper has been substantially supported by a grant from the Research Grants Council of the Hong Kong Special Administrative Region, China (Project No. HKU 712310E). Technical supports for the experimental tests provided by the laboratory staff of the Department of Civil Engineering, The University of Hong Kong, are gratefully acknowledged.

\section{LIST OF NOTATIONS}

$\begin{array}{ll}\text { NSC } & \text { Normal-strength concrete } \\ \text { RSC } & \text { High-strength concrete } \\ \text { NSCFST } & \text { Reinforced concrete } \\ \text { HSCFST } & \text { Normal-strength concrete-filled-steel-tubular } \\ D_{i} & \text { High-strength concrete-filled-steel-tubular } \\ D_{o} & \text { Outer diameter of inner tube of double-skinned CFST column } \\ t_{i} & \text { Outer diameter of outer tube of double-skinned CFST column } \\ t_{o} & \text { Thickness of inner tube of double-skinned CFST column } \\ r_{R} & \text { Thickness of outer tube of double-skinned CFST column } \\ A_{i} & \text { Radius of external steel bars } \\ A_{o} & \text { Cross-section area of the inner tube } \\ A_{c c} & \text { Cross-section area of the outer tube } \\ A_{R} & \text { Cross-section area of the core concrete } \\ \chi & \text { Cross-section area of external steel ring } \\ N & \text { Hollow section ratio } \\ N_{i} & \text { Load-carrying capacity of a specimen } \\ N_{o} & \text { Axial load taken by the inner tube } \\ N_{c c} & \text { Axial load taken by the outer tube } \\ N_{p} & \text { Axial load taken by the core concrete } \\ N_{p}{ }^{\prime} & \text { Axial strength of a specimen predicted by the proposed model } \\ N_{t} & \text { Axial strength of a specimen predicted by simplified formula } \\ f_{i} & \text { Experimentally measured axial strength of a specimen } \\ f_{o} & \text { Axial stress of the inner tube } \\ & \text { Axial stress of the outer tube }\end{array}$


$f_{c c} \quad$ Axial stress of the core concrete

$f_{c}{ }^{\prime} \quad$ Uni-axial concrete compressive strength represented by cylinder strength

$f_{r} \quad$ Confining pressure

$f_{r, \text { tube }} \quad$ Confining pressure provided by the outer tube

$f_{\text {r,ring }} \quad$ Confining pressure provided by external steel rings

$\sigma_{\theta, i}$

Hoop stress in inner tube of double-skinned CFST column

$\sigma_{\theta, o}$

Hoop stress in outer tube of double-skinned CFST column

$\sigma_{R}$

Tensile stress in external steel ring

$f_{y, i}$

Uni-axial yield strength of inner tube of double-skinned CFST column

$f_{y, o}$

Uni-axial yield strength of outer tube of double-skinned CFST column

$f_{y, R}$

Uni-axial yield strength of external steel ring

$n$

Number of external steel bars

$h \quad$ Height of the specimen

$s \quad$ Spacing of external steel rings

$\alpha_{\theta} \quad$ Hoop stress ratio

$G \quad$ Geometric factor

$\rho_{R} \quad$ Volumetric ratio of external rings to concrete

$V_{R} \quad$ Volume of steel rings

$V_{c} \quad$ Volume of concrete

\section{REFERENCES}

[1] Goldman, A. and Bentur, A., "The Influence of Microfillers on Enhancement of Concrete Strength”, Cement and Concrete Research, 1993, Vol. 23, No. 4, pp. 962-972.

[2] Haque, M. and Kayali, O., "Properties of High-strength Concrete Using a Fine Fly Ash", Cement and Concrete Research, 1998, Vol. 28, No. 10, pp. 1445-1452.

[3] Gettu, R., Bazant, Z.P. and Karr, M.E., "Fracture Properties and Brittleness of High-strength Concrete”, ACI Materials Journal, 1990, Vol. 87, No. 6, pp. 608-618.

[4] Cusson, D. and Paultre, P., "High-strength Concrete Columns Confined by Rectangular Ties", Journal of Structural Engineering, 1994, Vol. 120, No. 3, pp. 783-804.

[5] Marzouk, H. and Chen, Z., "Fracture Energy and Tension Properties of High-strength Concrete”, Journal of Materials in Civil Engineering, 1995, Vol. 7, No. 2, pp. 108-116.

[6] Zhou, F., Barr, B. and Lydon, F., "Fracture Properties of High Strength Concrete with Varying Silica Fume Content and Aggregates”, Cement and Concrete Research, 1995, Vol. 25, No. 3, pp. 543-552.

[7] Ho, J.C.M. and Zhou, K.J.H., "Limited Deformability Design of High-strength Concrete Beams in Low to Moderate Seismicity Regions”, Journal of Civil Engineering and Management, 2011, Vol. 17, No. 3, pp. 409-423.

[8] Wright, H., Oduyemi, T. and Evans, H., "The Experimental Behaviour of Double Skin Composite Elements”, Journal of Constructional Steel Research, 1991, Vol. 19, No. 2, pp. 97-110.

[9] Wei, S., Mau, S.T., Vipulanandan, C. and Mantrala, S.K., "Performance of New Sandwich Tube under Axial Loading: Experiment”, Journal of Structural Engineering, 1995, Vol. 121, No. 12, pp. 1806-1814.

[10] Zhao, X.L. and Grzebieta, R., "Strength and Ductility of Concrete Filled Double Skin (SHS Inner and SHS Outer) Tubes”, Thin-walled Structures, 2002, Vol. 40, No. 2, pp. 199-213. 
[11] Zhao, X.L., Grzebieta, R. and Elchalakani, M., “Tests of Concrete-filled Double Skin CHS Composite Stub Columns”, Steel and Composite Structures, 2002, Vol. 2, No. 2, pp.129-146.

[12] Giakoumelis, G. and Lam, D., "Axial Capacity of Circular Concrete-filled Tube Columns”, Journal of Constructional Steel Research, 2004, Vol. 60, No. 7, pp. 1049-1068.

[13] Tao, Z., Han, L.H. and Zhao, X.L., "Behaviour of Concrete-filled Double Skin (CHS Inner and CHS Outer) Steel Tubular Stub Columns and Beam-columns”, Journal of Constructional Steel Research, 2004, Vol. 60, No. 8, pp. 1129-1158.

[14] Young, B. and Ellobody, E., "Experimental Investigation of Concrete-filled Cold-formed High Strength Stainless Steel Tube Columns”, Journal of Constructional Steel Research, 2006, Vol. 62, No. 5, pp. 484-492.

[15] Dabaon, M., El-Khoriby, S., El-Boghdadi, M. and Hassanein, M.F., "Confinement Effect of Stiffened and Unstiffened Concrete-filled Stainless Steel Tubular Stub Columns”, Journal of Constructional Steel Research, 2009, Vol. 65, No. 8, pp. 1846-1854.

[16] Kuranovas, A., Goode, D., Kvedaras, A.K. and Zhong, S., "Load-bearing Capacity of Concrete-filled Steel Columns”, Journal of Civil Engineering and Management, 2009, Vol. 15, No. 1, pp. 21-33.

[17] de Oliveira, W.L.A., De Nardin, S., El Debs, A.L.H. and El Debs, M.K., "Evaluation of Passive Confinement in CFT Columns”, Journal of Constructional Steel Research, 2010, Vol. 66, No. 4, pp. 487-495.

[18] Szmigiera, E., Zoltowski, W. and Siennicki, M., "Research on Load Capacity of Concrete Filled Columns with Battened Steel Sections”, Journal of Civil Engineering and Management, 2010, Vol. 16, No. 3, pp. 313-319.

[19] Li, G.C., Lang, Y. and Yang, Z.J., "Behavior of High Strength CFSST Stub Columns with Inner CFRP Tube under Axial Compressive Load”, Advanced Steel Construction, 2011, Vol. 7, No. 3, pp. 239-254.

[20] Yu, F., He, S.H. and Niu, D.T., "Study on Unified Bearing Capacity of Rectangular Concrete-filled Steel Tubular Column Subjected to Axial Compression”, Advanced Steel Construction, 2012, Vol. 8, No. 1, pp. 95-111.

[21] Elchalakani, M., Zhao, X.L. and Grzebieta, R., "Concrete-filled Circular Seel Tubes Subjected to Pure Bending”, Journal of Constructional Steel Research, 2001, Vol. 57, No. 11, pp. 1141-1168.

[22] Lin, M. and Tsai, K.C., "Behavior of Double-skinned Composite Steel Tubular Columns Subjected to Combined Axial and Flexural Loads", Proceedings of the First International Conference on Steel and Composite Structures, Pusan, Korea, 14-16 June, 2001, pp. 1145-52.

[23] Chitawadagi, M.V. and Narasimhan, M.C., "Strength Deformation Behaviour of Circular Concrete Filled Steel Tubes Subjected to Pure Bending”, Journal of Constructional Steel Research, 2009, Vol. 65, No. 8, pp. 1836-1845.

[24] Lu, H., Han, L.H. and Zhao, X.L., "Analytical Behavior of Circular Concrete-filled Thin-walled Steel Tubes Subjected to Bending”, Thin-walled Structures, 2009, Vol. 47, No. 3, pp. 346-358.

[25] Kitada, T., "Ultimate Strength and Ductility of State-of-the-art Concrete-filled Steel Bridge Piers in Japan", Engineering Structures, 1998, Vol. 20, No. 4, pp. 347-354.

[26] Schneider, S.P., “Axially Loaded Concrete-filled Steel Tubes”, Journal of Structural Engineering, 1998, Vol. 124, No. 10, pp. 1125-1138.

[27] Elremaily, A. and Azizinamini, A., "Behavior and Strength of Circular Concrete-filled Tube Columns”, Journal of Constructional Steel Research, 2002, Vol. 58, No. 12, pp. 1567-1591.

[28] Varma, A.H., Ricles, J.M., Sause, R. and Lu, L.W., "Seismic Behavior and Modeling of High-strength Composite Concrete-filled Steel Tube (CFT) Beam-columns”, Journal of Constructional Steel Research, 2002, Vol. 58, No. 5, pp. 725-758. 
[29] Sakino, K., Nakahara, H., Morino, S. and Nishiyama, I., "Behavior of Centrally Loaded Concrete-filled Steel-tube Short Columns”, Journal of Structural Engineering, 2004, Vol. 130, No. 2, pp. 180-188.

[30] Yang, Y. and Han, L.H., “Concrete-filled Double-skin Tubular Columns under Fire”, Magazine of Concrete Research, 2008, Vol. 60, No. 3, pp. 211-222.

[31] Lu, H., Han, L.H. and Zhao, X.L., "Fire Performance of Self-consolidating Concrete Filled Double Skin Steel Tubular Columns: Experiments”, Fire Safety Journal, 2010, Vol. 45, No. 2, pp. 106-115.

[32] Zhao, X.L., Tong, L.W. and Wang, X.Y., “CFDST Stub Columns Subjected to Large Deformation Axial Loading”, Engineering Structures, 2010, Vol. 32, No. 3, pp. 692-703.

[33] Li, G.C., Sun, W. and Leon, R.T., "Hysteretic Performance of Steel Beam to Gangue CFST Column Connections with Ring Stiffeners under Low Reversed Cyclic Loading”, Advanced Steel Construction, 2011, Vol. 7, No. 2, pp. 173-181.

[34] Montejo, L.A., González-Román, L.A. and Kowalsky, M.J., "Seismic Performance Evaluation of Reinforced Concrete-filled Steel Tube Pile/Column Bridge Bents”, Journal of Earthquake Engineering, 2012, Vol. 16, No.3, pp. 401-424.

[35] Shakir-Khalil, H., "Composite Columns of Double-skinned Shells”, Journal of Constructional Steel Research, 1991, Vol. 19, No. 2, pp. 133-152.

[36] Yang, J., Xu, H. and Peng, G., "Behavior of Concrete-filled Double Skin Steel Tubular Columns with Octagon Section under Axial Compression”, Frontiers of Architecture and Civil Engineering in China, 2008, Vol. 2, No. 3, pp. 205-210.

[37] Huang, Y.H., Wang, R.H. and Huang, X.F., "Calculation of the Interfacial Tensile Stress of CFST Members under Axial Pressure”, Advanced Materials Research, 2011, Vol. 250, pp. 1638-1645.

[38] Köster, W. and Franz, H., "Poisson's Ratio for Metals and Alloys”, Metallurgical Reviews, 1961, Vol. 6, No. 1, pp. 1-56.

[39] Persson, B., "Poisson's Ratio of High-performance Concrete", Cement and Concrete Research, 1999, Vol. 29, No. 10, pp. 1647-1653.

[40] Ferretti, E., “On Poisson's Ratio and Volumetric Strain in Concrete”, International Journal of Fracture, 2004, Vol. 126, No. 3, pp. 49-55.

[41] Lu, X. and Hsu, C.T.T., “Tangent Poisson's Ratio of High-strength Concrete in Triaxial Compression”, Magazine of Concrete Research, 2007, Vol. 59, No. 1, pp. 69-77.

[42] Dong, C.X.; Ho, J.C.M., "Uni-axial Behaviour of Normal-strength CFDST Columns with External Steel Rings”, Steel and Composite Structures,2012, Vol. 13, No. 6, pp. 587-606.

[43] Ho, J.C.M. and Luo, L., "Uni-axial Behaviour of Normal-strength Concrete-filled-steel-tube Columns with External Confinement”, Earthquake and Structures, 2012. (in press)

[44] Lai, M.H. and Ho, J.C.M., "Behaviour of Uni-axially Loaded Concrete-filled-steel-tube Columns Confined by External Rings”, The Structural Design of Tall and Special Buildings, 2012, DOI: 10.1002/tal.1046.

[45] Huang, C., Yeh, Y.K., Liu, G.Y., Hu, H.T., Tsai, K., Weng, Y.T., Wang, S.H. and Wu, M.H., "Axial Load Behavior of Stiffened Concrete-filled Steel Columns”, Journal of Structural Engineering, 2002, Vol. 128, No. 9, pp. 1222-1230.

[46] Tao, Z., Han, L.H. and Wang, Z.B., "Experimental Behaviour of Stiffened Concrete-filled Thin-walled Hollow Steel Structural (HSS) Stub Columns”, Journal of Constructional Steel Research, 2005, Vol. 61, No. 7, pp. 962-983.

[47] Cai, J. and He, Z.Q., “Axial Load Behavior of Square CFT Stub Column with Binding Bars”, Journal of Constructional Steel Research, 2006, Vol. 62, No. 5, pp. 472-483.

[48] Tao, Z., Han, L.H. and Wang, D.Y., "Experimental Behaviour of Concrete-filled Stiffened Thin-walled Steel Tubular Columns”, Thin-walled Structures, 2007, Vol. 45, No. 5, pp. 517-527. 
[49] Tao, Z. and Han, L.H., "Behaviour of Concrete-filled Double Skin Rectangular Steel Tubular Beam-columns”, Journal of Constructional Steel Research, 2006, Vol. 62, No. 7, pp. 631-646.

[50] Tan, K.H. and Zhang, Y.F., "Compressive Stiffness and Strength of Concrete Filled Double Skin (CHS Inner \& CHS Outer) Tubes”, International Journal of Mechanics and Materials in Design, 2010, Vol. 6, No. 3, pp. 283-291.

[51] Uenaka, K., Kitoh, H. and Sonoda, K., "Concrete Filled Double Skin Circular Stub Columns under Compression”, Thin-walled Structures, 2010, Vol. 48, No.1, pp. 19-24.

[52] Hu, H.T. and Su, F.C., "Nonlinear Analysis of Short Concrete-filled Double Skin Tube Columns Subjected to Axial Compressive Forces”, Marine Structures, 2011, Vol. 24, No. 4, pp. 319-337.

[53] EC4, Eurocode 4, Eurocode 4: Design of Composite Steel and Concrete Structures: Part 1-1: General Rules and Rules for Buildings, UK, 2004.

[54] Han, L.H., Ren, Q.X. and Li, W., "Tests on Stub Stainless Steel-concrete-carbon Steel Double-skin Tubular (DST) Columns”, Journal of Constructional Steel Research, 2011, Vol. 67, No. 3, pp. 437-452.

[55] Mander, J. and Priestley, M.J.N., “Theoretical Stress-strain Model for Confined Concrete”, Journal of Structural Engineering, 1988, Vol. 114, No. 8, pp. 1804-1826.

[56] Hatzigeorgiou, G.D., "Numerical Model for the Behavior and Capacity of Circular CFT Columns, Part I: Theory”, Engineering Structures, 2008, Vol. 30, No. 6, pp. 1573-1578. 